\title{
Creep behaviour and microstructural evolution in AISI 316LN+Nb
}

\section{steels at $650^{\circ} \mathrm{C}$}

\section{Vlastimil Vodárek}

Technical University of Ostrava, 17. listopadu 15/2172, 70833 Ostrava-Poruba, Czech Republic

\begin{abstract}
The paper deals with the effect of niobium in the wrought AISI 316LN steels on the long-term creep characteristics at $650^{\circ} \mathrm{C}$. Casts B and C contained 0.1 and $0.3 \mathrm{wt} . \% \mathrm{Nb}$, respectively. As a reference material the niobium free Cast A was used. Small additions of niobium to the AISI $316 \mathrm{LN}$ steel resulted in a significant reduction of steady creep rate and shortening of the tertiary creep stage. At time to rupture exceeding $10^{4}$ hours the creep rupture strength of the niobium-bearing Casts B and C was slightly inferior to the Cast A. Two nitrides formed in the Casts B and C: Z-phase and $\mathrm{M}_{6} \mathrm{X}$. The steady creep rate in niobium-bearing casts was favourably affected by precipitation of the Zphase. The dimensional stability of Z-phase particles was very high, but niobium additions also accelerated the formation and coarsening of $\eta$-Laves and $\sigma$-phase. Coarse $\sigma$-phase particles at grain boundaries contributed significantly to the shortening of the tertiary creep stage.
\end{abstract}

\section{Keywords}

creep, microstructural evolution, phase stability, Z-phase, AISI 316LN+Nb steels

Corresponding author: Tel: +420 596994432

E mail address: vlastimil.vodarek@vsb.cz 


\section{Introduction}

The resistance of $\mathrm{CrNi}(\mathrm{Mo})$ austenitic stainless steels to dislocation creep depends on the stability of the microstructure, particularly the formation, dissolution and coarsening of precipitates [1,2]. Since many factors can influence the microstructure, it is not surprising that dramatic differences in creep rupture properties of austenitic stainless steels have been reported. The most important factors are chemical composition, thermo-mechanical pretreatments, temperature, stress and environment of creep tests [1]. The objectives are to develop a balance of creep strength with adequate creep rupture and room temperature ductilities. The matrix solid solution and a high number of the stable intragranular precipitates provide resistance to dislocation creep. The presence of grain boundary precipitates and the nature of precipitates determine grain boundary diffusion and sliding contributions to the creep rate.

One of the most successful methods of improving the long-term creep resistance of austenitic steels is based on increasing the extent of precipitation strengthening during creep exposure. This can be achieved by alloying of these steels with small amounts of strongly carbide or nitride forming elements, such as niobium or titanium. Keown and Pickering [3] showed that in the case of niobium stabilised steels optimum creep lives were obtained for the $\mathrm{Nb} / \mathrm{C}$ ratio matching the stoichiometry $\mathrm{Nb}_{4} \mathrm{C}_{3}$, and other studies [4] showed the optimum results for the $\mathrm{Nb} / \mathrm{C}$ atomic ratio of $1: 1$. However, in nitrogenbearing steels $\mathrm{NbX}$ particles can also dissolve nitrogen which makes the problem more complex [2]. The precipitation reactions in the usual AISI 300 grades of austenitic steels are well understood [1]. However, it is not true for the new generations of nitrogenbearing stabilised austenitic steels, such as 347LN, SAVE25 or NF709 [2]. A limited amount of information is available about phases such as a Z-phase which is a nitride 
with an ideal composition of $\mathrm{NbCrN} \mathrm{[5].} \mathrm{Conditions} \mathrm{of} \mathrm{the} \mathrm{Z-phase} \mathrm{formation} \mathrm{are} \mathrm{not}$ very clear and even less clear is its relative stability when compared with other carbonitrides [2,6]. Knowles [7] reported that Z-phase formed from MX precipitates, while Robinson and Jack [8] suggested its formation from solid solution. The conclusions of such a comparison must be examined carefully as the steel compositions were different. It is difficult as yet to build a coherent view of the various kinetics observed $[9,10]$. Another important and not well understood minor phase in nitrogenbearing austenitic stainless steels is $\mathrm{M}_{6} \mathrm{X}[2,11]$. This phase has a diamond cubic

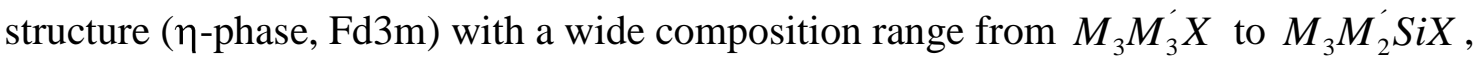
where $\mathrm{M}$ and $\mathrm{M}^{\prime}$ indicate substitutional elements, while $\mathrm{X}$ specifies an interstitial element, such as $\mathrm{N}$ or $\mathrm{C}[1]$.

The evolution of microstructure during creep exposure is of considerable interest, to ensure that no minor phase forms that is very detrimental to mechanical or other properties. This paper deals with the effect of small niobium additions to the wrought AISI 316LN steels on the creep rupture behaviour and the microstructural evolution during long-term creep exposure at $650^{\circ} \mathrm{C}$.

\section{Experimental materials and procedures}

The evaluation of creep properties was carried out on two casts of the AISI 316LN steel with additions of 0.1 and $0.3 \mathrm{wt} . \% \mathrm{Nb}$, respectively. As a reference material the niobium free AISI 316LN steel was used. Chemical compositions of all casts are given in Table 1. Temperatures of solution annealing, austenitic grain sizes and the yield points at $20^{\circ} \mathrm{C}$ for each wrought material in the as-received state are summarised in Table 2. Long-term creep rupture tests with a constant tensile load were carried out in air at temperature of 
$650^{\circ} \mathrm{C}$. The stress dependences of the time to rupture were described by the Seifert parametric equation [12]. The creep rupture strength values for the $10^{4}$ and $10^{5}$ hours at $650^{\circ} \mathrm{C}$ are for each cast shown in Table 2 . The creep ductility evaluation of individual casts was carried out using isothermal dependences of creep rupture elongation versus the time to rupture.

Microstructural investigations were conducted on the materials in the as-received state and on ruptured test-pieces of the casts investigated in order to understand the factors and processes responsible for the observed differences in creep behaviour. Investigations were carried out by means of light microscopy (LM) and transmission electron microscopy (TEM). Specimens were taken from both heads and gauge lengths of creep ruptured specimens. Thin foils for TEM investigations on a JEM 200CX microscope were prepared by twin-jet polishing (a Tenupol unit) in an electrolyte consisting of $95 \% \mathrm{CH}_{3} \mathrm{COOH}$ and $5 \% \mathrm{HClO}_{4}$ at room temperature and the voltage of $80 \mathrm{~V}$. Electron diffraction and EDS techniques were used for identification of minor phases on both carbon extraction replicas and thin foils.

\section{Results}

\subsection{Microstructure in the as-received state}

As evident from Table 2, small niobium additions resulted in a significant strengthening of steels. Grain sizes in niobium-bearing casts were markedly reduced. It suggested that some inhibiting particles were present in the austenitic matrix of niobium-bearing casts during solution annealing. In order to verify this hypothesis the following laboratory heat treatment was carried out on a specimen of the Cast C: $1300^{\circ} \mathrm{C} / 0.5$ hour $/$ water $+1100^{\circ} \mathrm{C} / 1.5$ hour $/$ water. 
Solution treatment at $1300^{\circ} \mathrm{C}$ was intended to dissolve particles of minor phases which had been present in the austenitic matrix. Microstructural investigations after this treatment confirmed only a few NbX particles in the austenitic matrix. Subsequent annealing at $1100^{\circ} \mathrm{C}$ resulted in heavy precipitation. Grain boundaries were decorated by a network of particles, a high number of fine particles was also present inside the austenitic grains, Fig. 1. Both intergranular and intragranular precipitates were identified as the Z-phase. The average size of intragranular rod-like Z-phase particles was about $110 \mathrm{~nm}$. Chemical composition of Z-phase particles, as determined by EDS, is shown in Table 3. As evident some molybdenum and iron are dissolved in the $\mathrm{NbCrN}$ phase (Z-phase).

The results of the above experiment are consistent with the published data. The solvus temperature of the $\mathrm{NbCrN}$ phase in austenitic stainless steels was reported to be between 1300 and $1350^{\circ} \mathrm{C}$, depending on the steel composition $[10,13,14]$. It is evident that the fine grain size of the Casts B and C in the as-received state is related to a high number of primary Z-phase particles in the austenitic matrix.

\subsection{Creep rupture behaviour}

The results of creep rupture tests at $650^{\circ} \mathrm{C}$ are summarised in Fig. 2. At short times to rupture all casts investigated revealed approximately the same level of creep rupture strength, in spite of significantly smaller austenitic grain size in the niobium-bearing casts. At times to rupture exceeding $10^{4}$ hours the creep rupture strength of casts with niobium additions was slightly inferior to the niobium free Cast A, see Table 2 . The growing niobium content strongly reduced the minimum creep rate and prolonged the time to the onset of the tertiary stage of creep. However, the enhanced creep 
resistance of the niobium-bearing casts in the primary and secondary stages is not accompanied by the longer creep lives that might have been expected. Selected parameters of creep curves at $650^{\circ} \mathrm{C} / 100 \mathrm{MPa}$ are for each cast shown in Table 4 . It is virtually impossible to predict creep life from an experimentally ascertained steady-state creep rate.

Fig. 3 shows how the creep elongation varied with the time to rupture. The niobium free Cast A shows a marked rise of the elongation values at times to rupture longer than $10^{3}$ hours, and a maximum at times in excess of $10^{4}$ hours. The niobium-bearing casts differ from this pattern, showing no well--defined trend at times to rupture shorter than $10^{4}$ hours and a pronounced decline of creep ductility at the longer times, Fig. 3. The observed differences in creep ductility are decisively affected by failure mechanisms which depend on the temperature, applied stress and microstructural evolution during creep exposure [1].

\subsection{Microstructural evolution during creep}

Precipitation reactions in the niobium free Cast A started with the formation of a small amount of $\mathrm{Cr}_{2} \mathrm{~N}$ phase and $\mathrm{M}_{23} \mathrm{C}_{6}$ particles, preferentially at grain boundaries. Prolonging the creep exposure was accompanied by a gradual replacement of $\mathrm{Cr}_{2} \mathrm{~N}$ particles at grain boundaries by $\eta$-Laves and finally by $\sigma$-phase particles, Fig. 4. Furthermore, $\mathrm{M}_{23} \mathrm{C}_{6}$ particles were gradually replaced by $\mathrm{M}_{6} \mathrm{X}$ phase. Chemical composition of this phase corresponded to the $\mathrm{Cr}_{3} \mathrm{Ni}_{2} \mathrm{SiX}$ type. Diffraction studies in the [001] orientation revealed a systematic extinction of hk0 reflections for which $h+k \neq 4 n$ ( $\mathrm{n}$ being an integral number), Fig. 5. This is due to a diamond glide plane in the space group of $\eta$-phase $\left(M_{6} X\right)$. After creep exposure for approximately 30000 hours most 
intergranular particles in Cast A were identified as $\sigma$-phase with a low fraction of $\mathrm{M}_{6} \mathrm{X}$ phase, while other minor phases were predominantly found inside the austenitic grains [11]. In spite of a nearly continuous network of fine $\sigma$-phase particles along grain boundaries, the creep ductility was high. However, as the exposure time prolongs, the particles of $\sigma$-phase and other minor phases coarsen, and this facilitates the nucleation of cavities. It causes a reduction of creep ductility. A LM micrograph of the microstructure after creep exposure for 132 524hours is shown in Fig. 6. Figs. 7a and 7b show coarse $\eta$-Laves and $\sigma$-phase intragranular particles, respectively. In the course of creep exposure at $650^{\circ} \mathrm{C}$ only a very small amount of $\chi$-phase was detected. The same precipitation sequence was found in both heads and gauge lengths of creep ruptured specimens.

Results of studies on the minor phase evolution in Cast B are summarised in Table 5. Intragranular primary Z-phase, $\eta$-Laves and very fine secondary Z-phase particles in the specimen after exposure for 483 hours are shown in Fig. 8. Secondary Z-phase particles formed during creep, preferentially on dislocations. Furthermore, in this specimen a small number of chromium rich $\mathrm{M}_{23} \mathrm{C}_{6}$ carbides was identified at grain boundaries. This minor phase was gradually replaced by $\mathrm{M}_{6} \mathrm{X}$ phase $\left(\mathrm{Cr}_{3} \mathrm{Ni}_{2} \mathrm{SiX}\right.$ type $)$ at longer creep exposures. During long-term creep exposures secondary Z-phase particles continued to precipitate on dislocations and also at grain boundaries. Fig. 9 shows pinning of dislocations by secondary Z-phase particles. Particles of Z-phase were very dimensionally stable, even after 58 936hours the average size of secondary Z-phase particles reached only $14 \mathrm{~nm}$, Fig. 10. Intragranular $\eta$-Laves $\left(\mathrm{Fe}_{2} \mathrm{Mo}\right.$ type $)$ particles in the form of needles continued to grow with the prolonging time of creep/thermal exposure. Intensive intragranular precipitation of $\eta$-Laves needles, primary and 
secondary Z-phase particles are for the specimen after creep exposure for 14 864hours shown in Fig. 11. In this specimen the first appearance of $\sigma$-phase was recorded. Particles of this phase formed preferentially at grain boundaries. The rate of $\sigma$-phase coarsening was very high. Coarse $\sigma$-phase particles were surrounded by denuded zones which facilitated grain-boundary sliding. After long-term creep exposure two dominant minor phases at grain boundaries were $\sigma$-phase and $\mathrm{M}_{6} \mathrm{X}$.

The precipitation reactions in the Cast $\mathrm{C}$ are summarised in Table 6 . In the course of the long-term creep/thermal exposure the same minor phases formed as in the Cast B. Secondary Z-phase particles precipitated preferentially on dislocations and at grain boundaries, Fig. 12. Due to the higher niobium content in the Cast $\mathrm{C}$ the intensity of Z-phase precipitation was higher than that in the Cast B. The dimensional stability of Z-phase particles during long-term creep exposure was very high. The average size of secondary Z-phase particles after exposure for 81hours and 37 890hours reached only $6 \mathrm{~nm}$ and $12 \mathrm{~nm}$, respectively [11]. $\mathrm{M}_{23} \mathrm{C}_{6}$ carbides at grain boundaries were gradually replaced by $\mathrm{M}_{6} \mathrm{X}$ phase $\left(\mathrm{Cr}_{3} \mathrm{Ni}_{2} \mathrm{SiX}\right.$ type $)$. The kinetics of the both $\sigma$-phase and $\eta$-Laves formation was even faster than that in the Cast B. Particles of $\sigma$-phase preferentially formed at grain boundaries, Figs. 12 and 13. Only a small fraction of $\sigma$-phase particles was detected inside austenitic grains. The coarsening rate of this phase was very high. After long-term exposure at $650^{\circ} \mathrm{C}$ grain boundaries were mainly decorated by $\sigma$-phase and $\mathrm{M}_{6} \mathrm{X}$ particles, while intensive precipitation of $\eta$-Laves and Z-phase was observed inside austenitic grains. Coarse $\sigma$-phase particles (up to $10 \mu \mathrm{m}$ ) at grain boundaries were surrounded by the denuded zones. These coarse $\sigma$-phase particles facilitated the formation of intergranular creep cavities, Fig. 14. In the niobium-bearing Casts B and C 
the same precipitation sequence was found in both heads and gauge lengths of creep ruptured specimens.

\section{Discussion}

The precipitation in the niobium free Cast A was in accordance with the generally agreed knowledge about the precipitation reactions in the AISI 316LN steels [1]. After long-term creep/thermal exposure at $650^{\circ} \mathrm{C}$ the following minor phases were present in the austenitic matrix: $\mathrm{M}_{6} \mathrm{X}, \eta$-Laves and $\sigma$-phase.

The results of microstructural investigations proved that the precipitation sequence in the Casts $\mathrm{B}$ and $\mathrm{C}$ during creep at $650^{\circ} \mathrm{C}$ was identical: fine secondary Z-phase particles, chromium rich $\mathrm{M}_{23} \mathrm{C}_{6}$ particles which were gradually replaced by $\mathrm{M}_{6} \mathrm{X}$, $\eta$ Laves and $\sigma$-phase [15].

The $\mathrm{Nb} / \mathrm{C}$ ratio is in the Cast $\mathrm{B}$ below and in the Cast $\mathrm{C}$ over the MX stoichiometric ratio (the weight ratio for $\mathrm{NbC}$ is about $8: 1$ ), Table 7 . When we take into account nitrogen, then $\mathrm{Nb} /(\mathrm{C}+6 / 7 \mathrm{~N})$ ratios for the both casts are low and competition for niobium between $\mathrm{NbX}$ and $\mathrm{NbCrN}$ phases is to be expected. The results of microstructural investigations proved that Z-phase was fast enough to form first.

Dimensional stability of secondary Z-phase particles forming during creep exposure at $650^{\circ} \mathrm{C}$ was excellent. No $\mathrm{NbX}$ particles were found to precipitate during long-term creep exposure. This demonstrates that in the steels investigated, Z-phase is at $650^{\circ} \mathrm{C}$ more stable than $\mathrm{NbX}$. Furthermore, no $\mathrm{Cr}_{2} \mathrm{~N}$ particles were detected. A small amount of $\mathrm{M}_{23} \mathrm{C}_{6}$ particles formed at grain boundaries and incoherent twin boundaries in the Casts B and C at short times of creep exposure. This phase was gradually replaced by $\mathrm{M}_{6} \mathrm{X}\left(\mathrm{Cr}_{3} \mathrm{Ni}_{2} \mathrm{SiX}\right.$ type $)$ phase at longer exposures. In nitrogen- 
bearing austenitic steels $\mathrm{M}_{6} \mathrm{X}$ phase is regarded as a nitride [10]. Typical contents of substitutional elements in this phase, as determined by EDS, are shown in Table 8. The niobium content in this phase is low.

Elements like $\mathrm{Cr}, \mathrm{Nb}, \mathrm{Ti}$ and Mo are known to promote the formation of $\sigma$-phase and therefore its formation is faster in stabilised austenitic grades [16]. Also Si promotes and accelerates its formation [1,2]. The kinetics of the $\sigma$-phase formation and coarsening in the niobium free AISI 316LN cast was much slower than in the niobiumbearing Casts B and C [15]. The $\sigma$-phase coarsening was the most pronounced in the Cast $\mathrm{C}$ containing $0.3 \mathrm{wt} . \% \mathrm{Nb}$. The coarse $\sigma$-phase particles at grain boundaries facilitated the formation and interlinking of creep cavities and contributed to relatively poor creep ductility. The composition of $\sigma$-phase, as determined by EDS, is shown in Table 8.

Niobium in the Casts B and C also accelerated $\eta$-Laves precipitation. This phase started to form at grain and incoherent twin boundaries. At longer times of exposure an intensive precipitation of $\eta$-Laves in the form of needles was observed inside austenitic grains. In niobium stabilised steels, the $\mathrm{Fe}_{2} \mathrm{Nb}$ phase has frequently been reported after long aging times. It is a transient phase which disappears when the $\mathrm{Fe}_{3} \mathrm{Nb}_{3} \mathrm{C}\left(\mathrm{M}_{6} \mathrm{C}\right)$ forms [1]. However, $\eta$-Laves in the Casts $\mathrm{B}$ and $\mathrm{C}$ corresponded to the $\mathrm{Fe}_{2} \mathrm{Mo}$ phase. The composition of this phase, as determined by EDS, is shown in Table 8. The niobium content in both $\eta$-Laves and $\sigma$-phase is low. Based on the typical size, the precipitates in the Casts B and C after long-term creep/thermal exposure at $650^{\circ} \mathrm{C}$ can be classified as follows: most short rod-like secondary Z-phase particles were finer than $50 \mathrm{~nm}, \mathrm{M}_{6} \mathrm{X}, \eta$-Laves and primary Z-phase 
particles were usually in the range from 0.1 to $1 \mu \mathrm{m}$ and the coarse $\sigma$-phase particles reached from 1 to $10 \mu \mathrm{m}$.

Only two nitrogen rich minor phases were identified in the niobium-bearing Casts B and C: Z-phase and $\mathrm{M}_{6} \mathrm{X}$. The kinetics of the Z-phase formation was much faster than that of $\mathrm{M}_{6} \mathrm{X}$. It can be expected that these two minor phases will compete for nitrogen. However, time to rupture of about 60000 hours at $650^{\circ} \mathrm{C}$ in creep specimens is not sufficiently long to assess the relative stability of these nitrogen-bearing minor phases. The enhanced creep resistance of the niobium-bearing casts in the primary and secondary stages is not accompanied by the longer creep lives that might have been expected. The fast coarsening of $\sigma$-phase in the niobium-bearing casts resulted in the formation of a discontinuous network of coarse particles along grain boundaries. Such particles facilitated the development of creep damage and contributed to the relatively poor creep ductility of the niobium-bearing casts. Differences in the character of intergranular precipitation in the Casts $\mathrm{A}$ and $\mathrm{C}$ after long-term creep exposure at $650^{\circ} \mathrm{C}$ are evident from Figs. 6 and 15, respectively.

\section{Conclusions}

1. Small additions of niobium to the AISI $316 \mathrm{LN}$ steel resulted in a significant reduction of steady creep rate and shortening of the tertiary creep stage. At times to rupture exceeding $10^{4}$ hours the creep rupture strength of the niobium-bearing Casts B and $\mathrm{C}$ was slightly inferior to the niobium free Cast $\mathrm{A}$.

2. The following minor phases were identified in the niobium-bearing Casts B and $\mathrm{C}$ after long-term creep/thermal exposure at $650^{\circ} \mathrm{C}$ : Z-phase, $\eta$-Laves, $\mathrm{M}_{6} \mathrm{X}$ and $\sigma$-phase. 
3. The positive effect of niobium in the AISI316LN steels on a reduction of secondary creep rate due to secondary Z-phase precipitation was gradually surpassed by the niobium effect on acceleration of the $\sigma$-phase and $\eta$-Laves formation. Coarse $\sigma$-phase particles facilitated the development of creep damage.

4. Only two nitrogen rich minor phases were present in the Casts B and C: Z-phase and $\mathrm{M}_{6} \mathrm{X}$. The kinetics of the Z-phase formation was faster than that of $\mathrm{M}_{6} \mathrm{X}$. Creep specimens with time to rupture about 60000 hours at $650^{\circ} \mathrm{C}$ are not sufficiently long to assess the relative stability of these phases. The dimensional stability of Z-phase particles was excellent. $\mathrm{M}_{6} \mathrm{X}$ particles grew/coarsened much faster.

5. It has been demonstrated that an improvement of resistance to dislocation creep by an addition of a strong carbide/nitride forming element to steels does not only depend on the formation of fine and stable intragranular precipitates but also on the effect of this element on the stability of other minor phases.

\section{Acknowledgements}

The author wishes to acknowledge the financial support from the Grant Agency of the Czech Republic under the project No. 106/09/1868 and from the Regional Materials Science and Technology Centre No. CZ.1.05/2.1.00/01.0040.

\section{References}

[1] P. Marshall, Austenitic Stainless Steels, Elsevier, London - New York, 1984.

[2] T. Sourmail, Mat. Sci. Techn. 17 (2001) 1-14. 
[3] S. R. Keown, F. B. Pickering, in: Proc. Creep Strength in Steels and High Temperature Alloys, The Metals Society, London, 1974, pp. 229-234.

[4] J. M. Adamson, J.W. Martin, JISI 210 (1972) 271-275.

[5] D.H. Jack and K.H. Jack, JISI 209 (1972) 790-792.

[6] A. Raghavan, C. F. Klein, C. N. Marzinski, Metall. Trans. A 23 (1992) 2455-2462.

[7] G. Knowles, Metal Science 11 (1977) 117-122.

[8] P.W. Robinson, D. H. Jack, in: R. Lula (Ed.), Proc. New Developments in Stainless Steel Technology, ASM, Metals Park, OH, 1985, pp. 71-76.

[9] N.D. Evans, P.J. Masiasz, J.P. Shingledecker, M.J. Pollard, Metall. Mater. Trans. A 41 (2010) 3032-3040.

[10] T. Sourmail, H.K.D.H. Bhadeshia, Metall. Mater. Trans. A 36 (2005) 23-34.

[11] V. Vodárek, M. Sobotková, J. Sobotka, in: A. Strang, J. Cawley, G.W. Greenwood (Eds.), Proc. Microstructural Stability of Creep Resistant Alloys for High Temperature Plant Applications, The Institute of Materials, London, 198, pp. 69-88.

[12] J. Sobotka, V. Vodárek, M. Sobotková, Metallurgical Journal 47 (1992) 31-36 (in Czech).

[13] H. Hughes, JISI 205 (1967) 775-778.

[14] V. Vodárek, Scripta Metall. Mater. 25 (1991) 549-552.

[15] V. Vodárek, M. Liška, J. Sobotka, in: A.G. Svyazhin, V.G. Prokoshkina, K.L. Kossyrev (Eds) Proc. of the $10^{\text {th }}$ Int. Conf. on High Nitrogen Steels, MISIS, Moscow, 2009, pp. 83-89.

[16] Y. Minami, H. Kimura, Z. Ihara, Mat. Sci. Techn. 2 (1986) 795-806. 


\section{Research highlights}

- We studied the effect of $\mathrm{Nb}$ additions to AISI 316LN steels on creep and microstructure at $650^{\circ} \mathrm{C}$.

- $\mathrm{Nb}$ additions resulted in a reduction of secondary creep rate and shortening of the tertiary stage.

- Two nitrogen rich minor phases were present in the niobium-bearing casts: Z-phase and $\mathrm{M}_{6} \mathrm{X}$.

- The dimensional stability of Z-phase during creep at $650^{\circ} \mathrm{C}$ was much better than that of $\mathrm{M}_{6} \mathrm{X}$.

- $\mathrm{Nb}$ accelerated $\sigma$-phase and $\eta$-Laves formation and this surpassed the positive effect of Z-phase. 


\section{Captions}

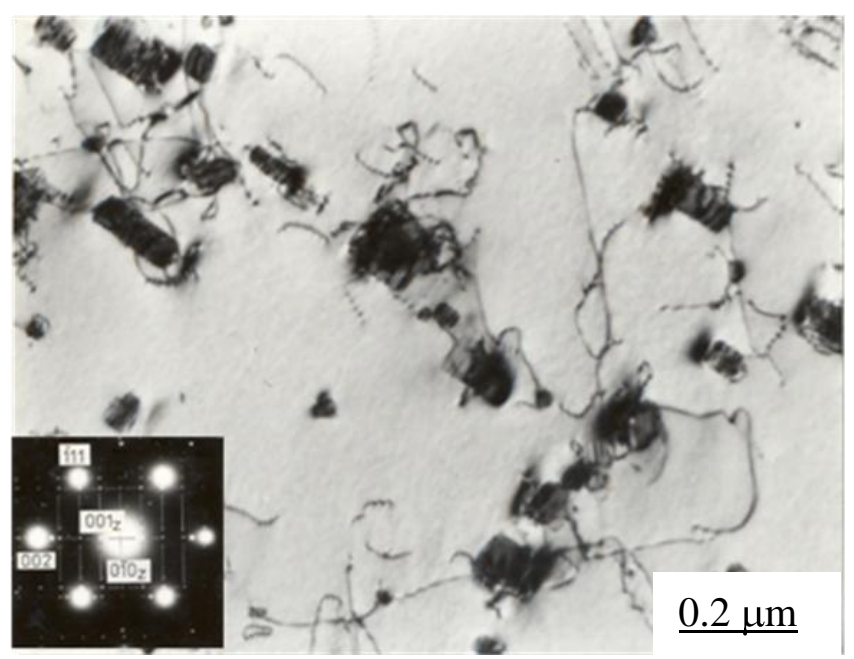

Fig. 1 Prim. Z-phase particles in the Cast $\mathrm{C}$ specimen after laboratory heat treatment, SADP:

$$
[110]_{\gamma}+[100]_{Z}
$$




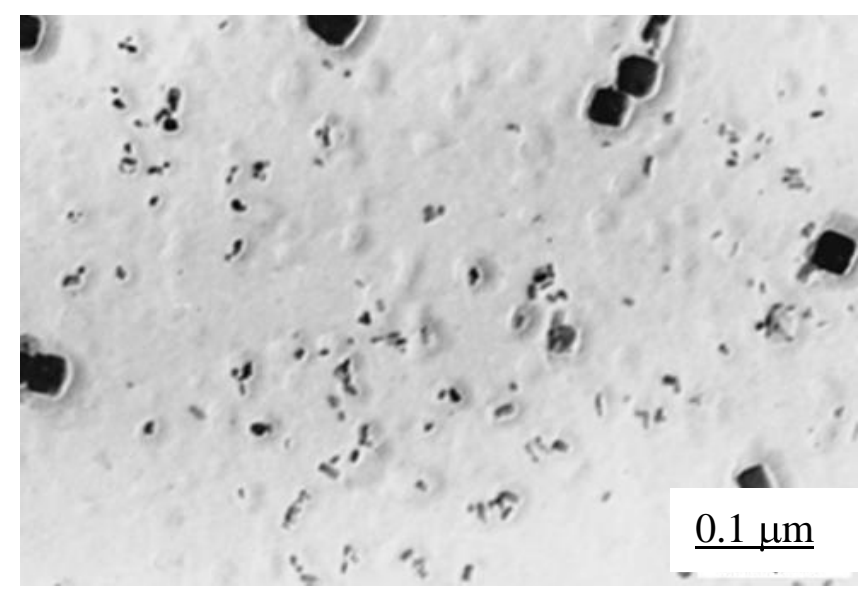

Fig. 10 Intragranular prim. and sec. Z-phase particles, $650^{\circ} \mathrm{C} / 58936 \mathrm{~h}$., Cast B 


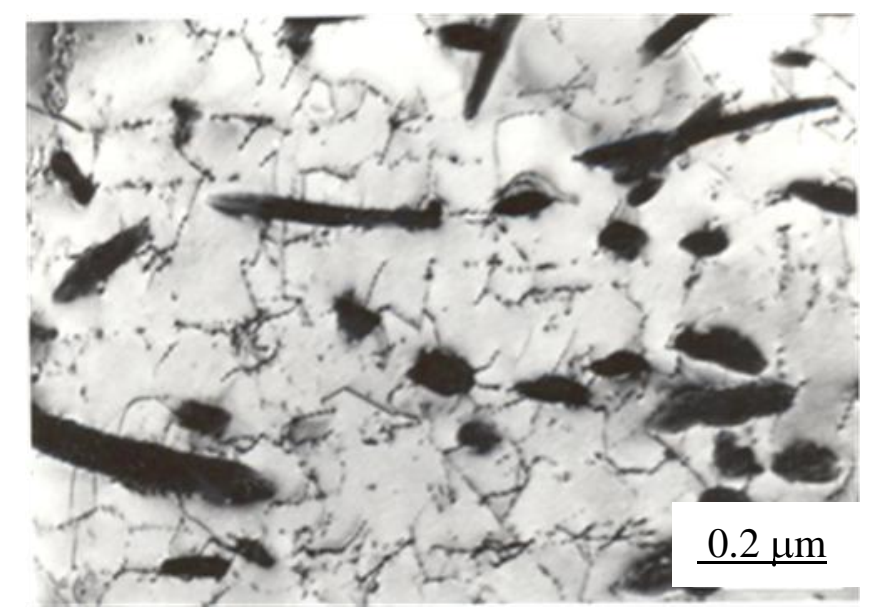

Fig. $11 \eta$-Laves and prim. Z-phase rods, fine sec. Z-phase particles on dislocations, $650^{\circ} \mathrm{C} / 14$ 864h., Cast B 


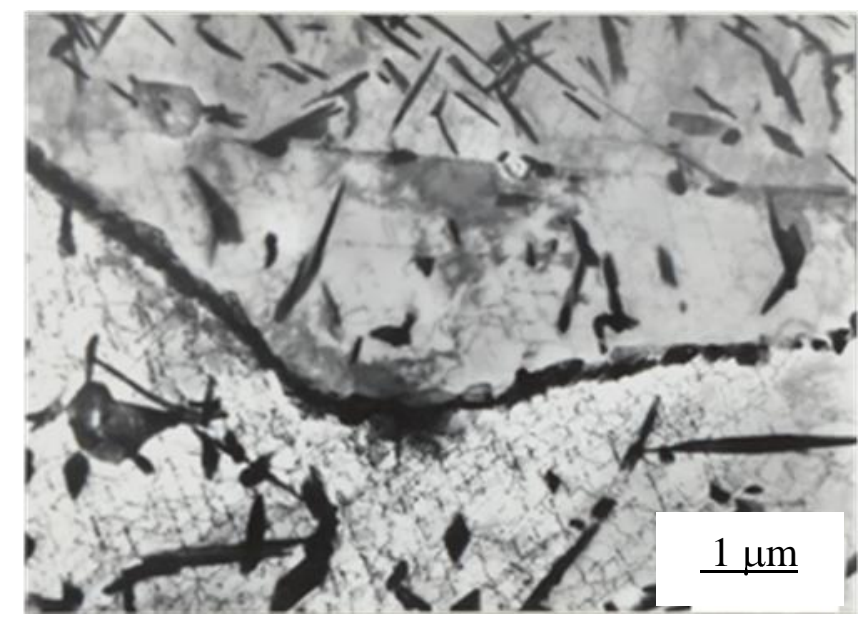

Fig. 12 Network of $\sigma$-phase, $\mathrm{M}_{6} \mathrm{X}$ and prim. Z-phase particles at grain boundary, intragranular $\eta$-Laves rods, sec. Z-phase particles on dislocations, $650^{\circ} \mathrm{C} / 37890 \mathrm{~h}$., Cast C 


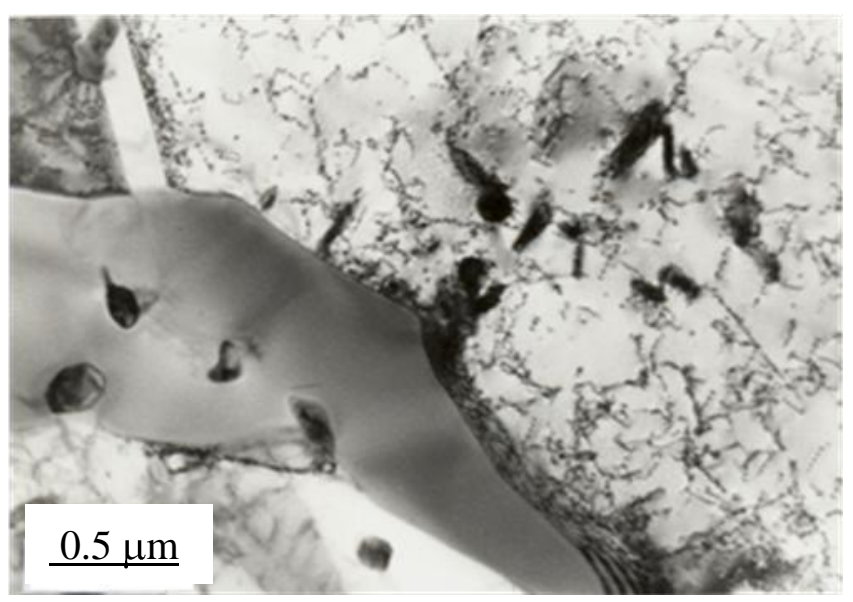

Fig. 13 Intergranular coarse $\sigma$-phase particle, intragranular $\eta$-Laves, sec. Z-phase particles on dislocations, $650^{\circ} \mathrm{C} / 26505 \mathrm{~h}$., Cast $\mathrm{C}$ 


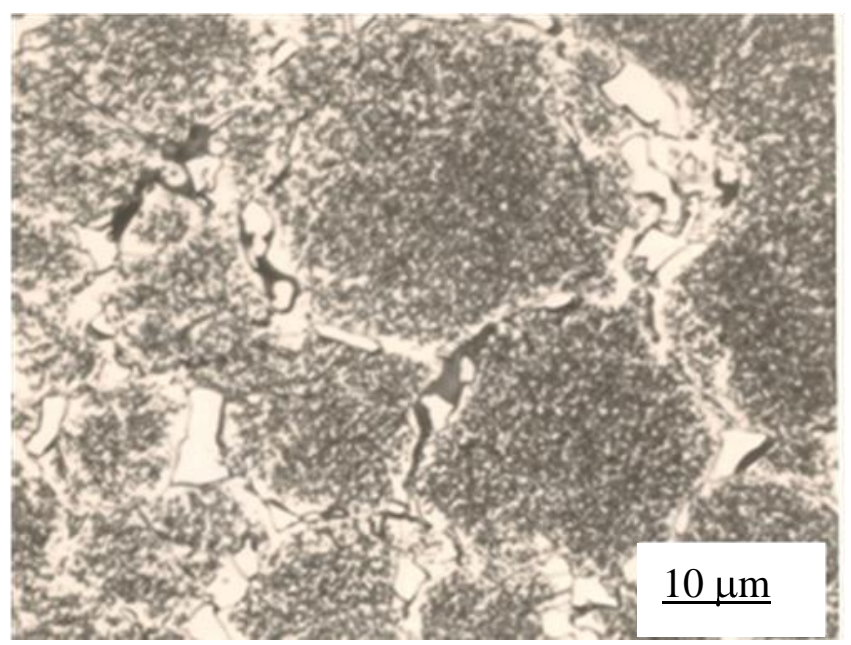

Fig. 14 Creep cavities formed on coarse intergranular $\sigma$-phase particles, $650^{\circ} \mathrm{C} / 33$ 624h., Cast C 


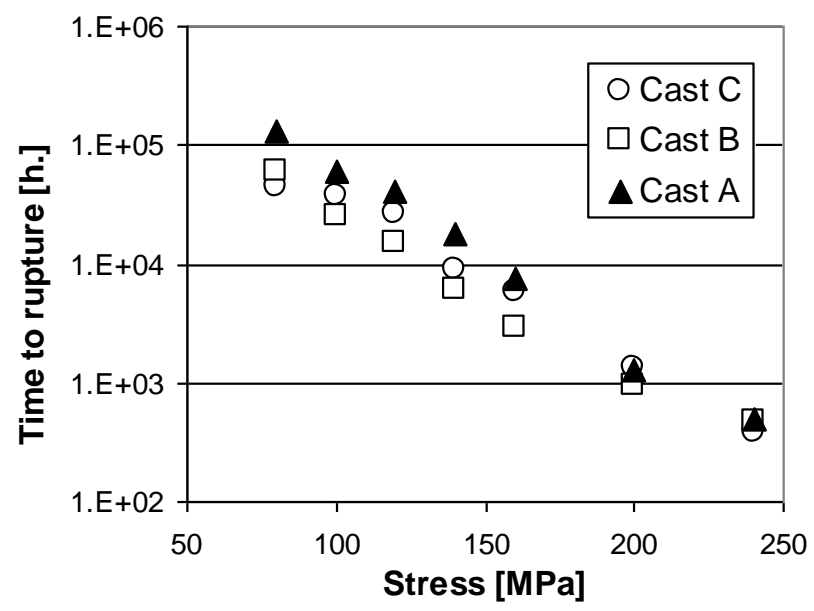

Fig. 2 Stress dependences of time to rupture at $650^{\circ} \mathrm{C}$ 


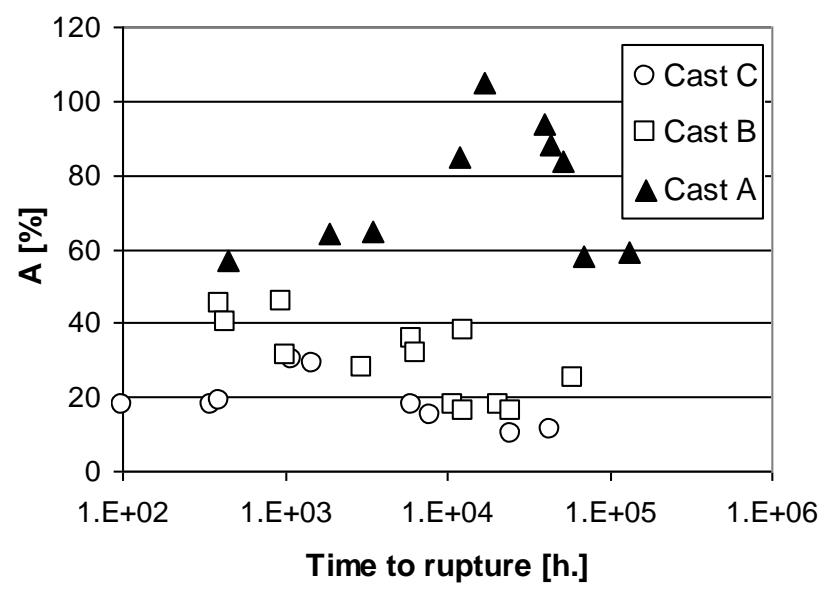

Fig. 3 Time to rupture versus creep rupture ductility at $650^{\circ} \mathrm{C}$ 


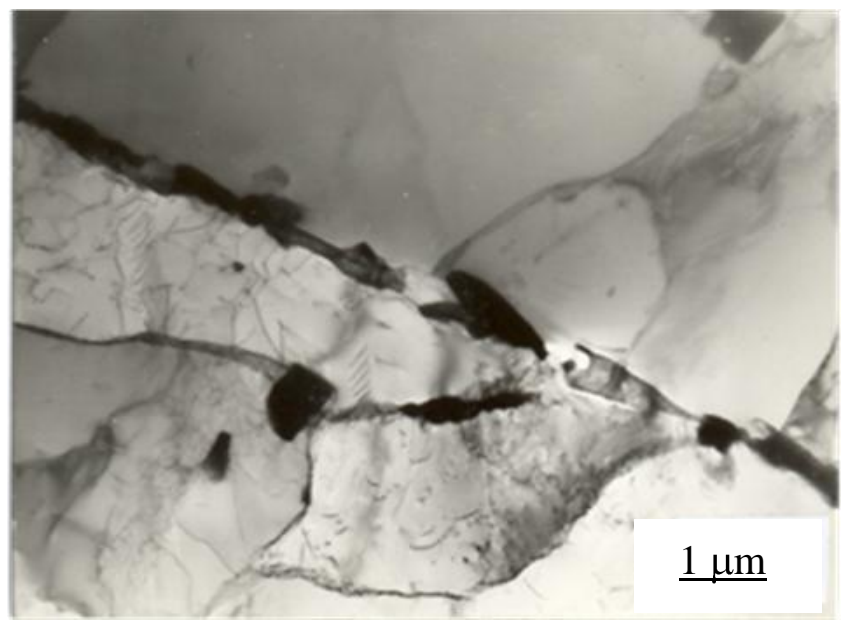

Fig. 4 Continuous network of $\sigma$-phase particles after creep exposure $650^{\circ} \mathrm{C} / 59496 \mathrm{~h}$., Cast A 


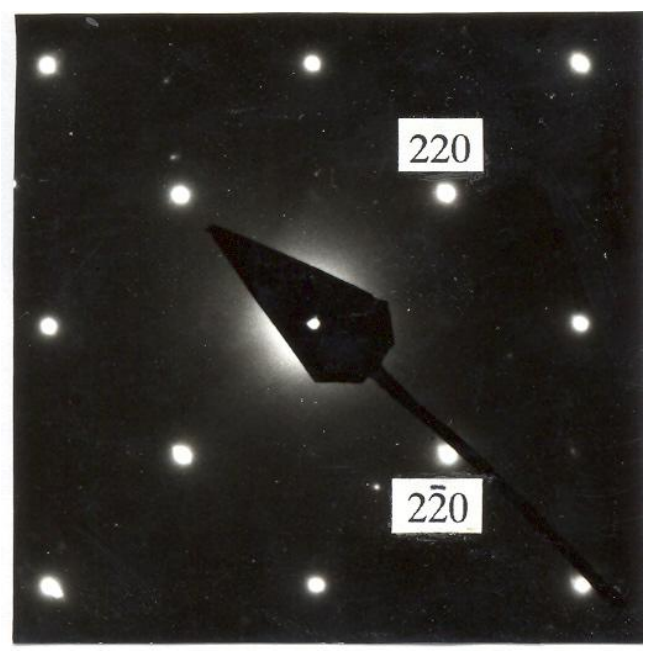

Fig. 5 Diffraction pattern along the [001] direction of $\mathbf{M}_{6} \mathrm{X}$, an extinction of 200,420, etc. spots of $\eta$-phase 


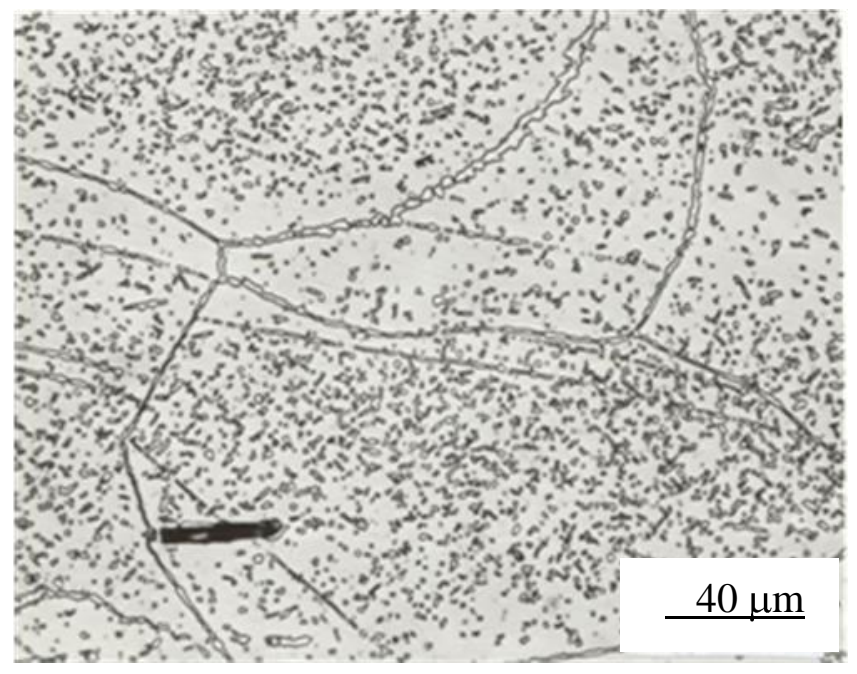

Fig. 6 Microstructure of the Cast A after creep exposure $650^{\circ} \mathrm{C} / 132524 \mathrm{~h}$. 


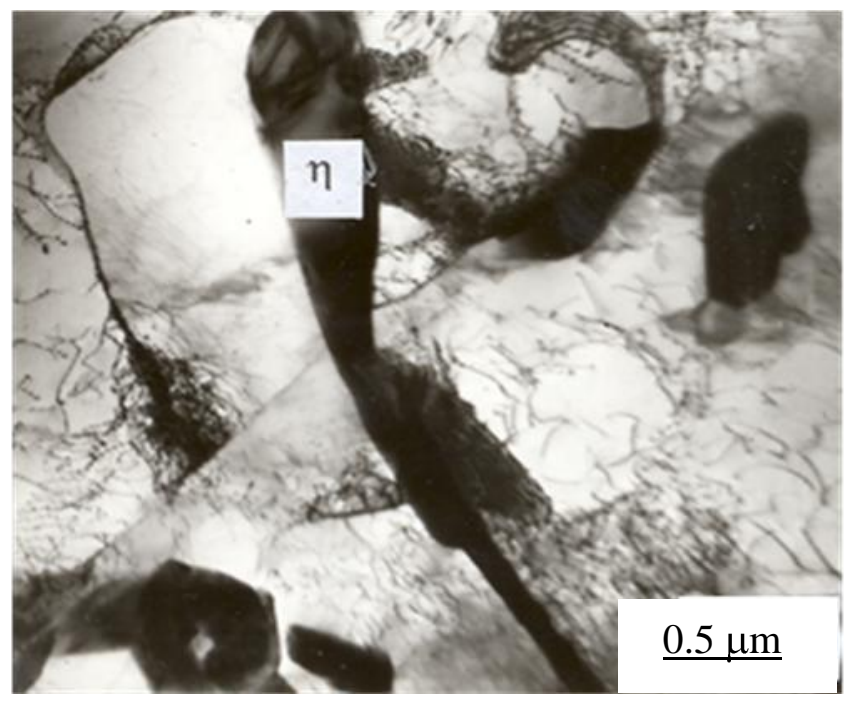

(a)

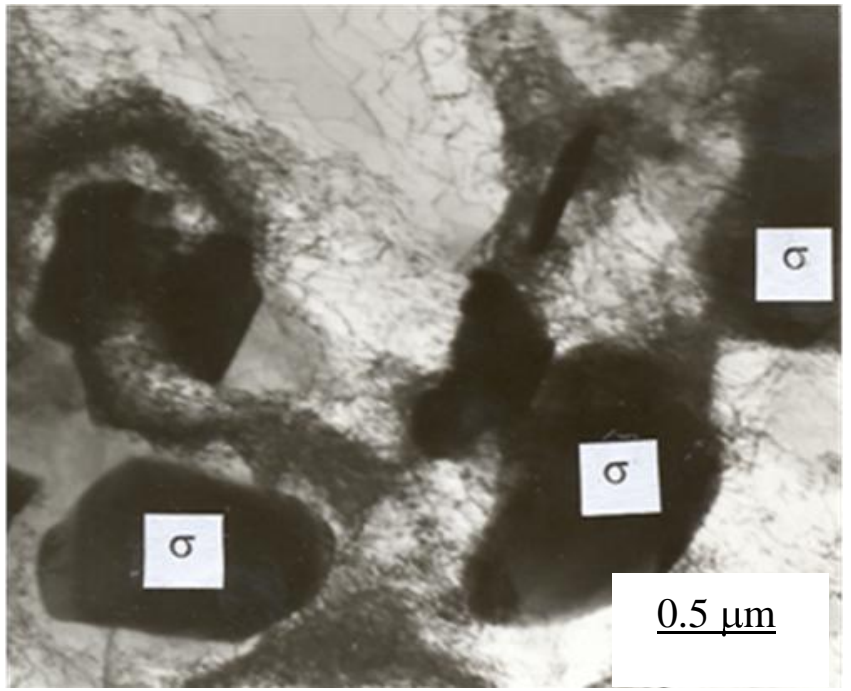

(b)

Fig. 7 Intragranular $\eta$-Laves (a) and $\sigma$-phase (b) precipitation after creep exposure $650^{\circ} \mathrm{C} / 132524 h .$, Cast A 


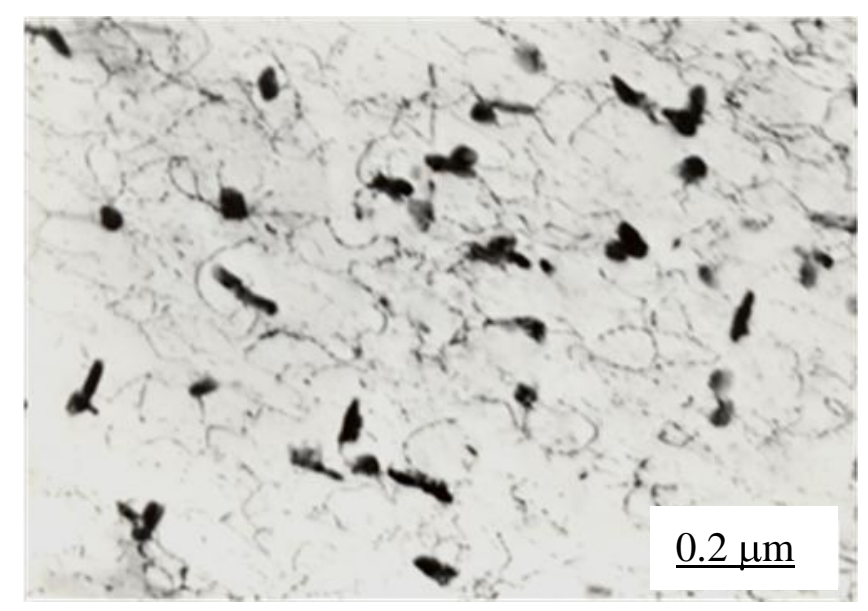

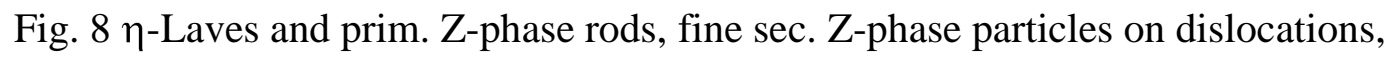
$650^{\circ} \mathrm{C} / 483 \mathrm{~h}$., Cast B 


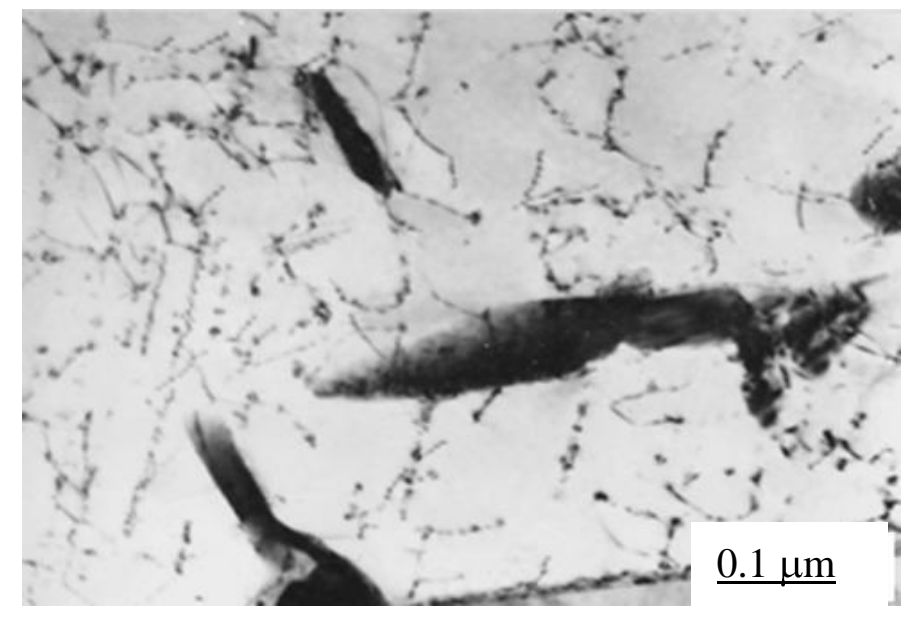

Fig. 9 Pinning of dislocations by fine sec. Z-phase particles, $650^{\circ} \mathrm{C} / 58936 \mathrm{~h}$, Cast B 


\section{Tables}

Table 1 Chemical compositions of the casts investigated, wt.\%

\begin{tabular}{cccccccccccc}
\hline Cast & $\mathrm{C}$ & $\mathrm{N}$ & $\mathrm{Mn}$ & $\mathrm{Si}$ & $\mathrm{P}$ & $\mathrm{S}$ & $\mathrm{Cr}$ & $\mathrm{Ni}$ & $\mathrm{Mo}$ & $\mathrm{B}$ & $\mathrm{Nb}$ \\
\hline $\mathrm{A}$ & 0.023 & 0.145 & 2.50 & 0.27 & 0.015 & 0.017 & 17.8 & 14.6 & 2.68 & 0.0037 & $<0.003$ \\
$\mathrm{~B}$ & 0.023 & 0.161 & 1.34 & 0.48 & 0.014 & 0.013 & 18.1 & 12.5 & 2.82 & 0.0012 & 0.106 \\
$\mathrm{C}$ & 0.021 & 0.158 & 1.11 & 0.42 & 0.025 & 0.009 & 17.8 & 12.6 & 2.64 & 0.0020 & 0.300 \\
\hline
\end{tabular}

Table 2 Temperatures of solution annealing, austenitic grain sizes and mechanical properties

\begin{tabular}{cccccc}
\hline Cast & $\mathrm{T}$ & $\mathrm{d}$ & $\mathrm{R}_{\mathrm{p}} 0.2$ & $\mathrm{R}_{\mathrm{m} / 650^{\circ} \mathrm{C} / 10^{4} \mathrm{~h} .}$ & $\mathrm{R}_{\mathrm{m} / 650^{\circ} \mathrm{C} / 10^{5} \mathrm{~h} .}$ \\
& {$\left[{ }^{\circ} \mathrm{C}\right]$} & {$[\mathrm{mm}]$} & {$[\mathrm{MPa}]$} & {$[\mathrm{MPa}]$} & {$[\mathrm{MPa}]$} \\
\hline $\mathrm{A}$ & 1100 & 0.120 & 285 & 147 & 86 \\
\hline $\mathrm{B}$ & 1050 & 0.020 & 392 & 130 & 71 \\
\hline $\mathrm{C}$ & 1120 & 0.029 & 349 & 144 & 77 \\
\hline
\end{tabular}

Table 3 Chemical composition of primary Z-phase, wt.\%

\begin{tabular}{cccc}
\hline $\mathrm{Cr}$ & $\mathrm{Fe}$ & $\mathrm{Nb}$ & $\mathrm{Mo}$ \\
\hline 26 & 8 & 61 & 5 \\
\hline
\end{tabular}


Table 4 Selected parameters of creep curves at $650^{\circ} \mathrm{C} / 100 \mathrm{MPa}$

\begin{tabular}{ccccc}
\hline Cast & $\varepsilon_{\mathrm{S}} \cdot 10^{10}\left[\mathrm{~s}^{-1}\right]$ & $\mathrm{t}_{3}[\mathrm{~h}]$ & $\mathrm{t}_{\mathrm{r}}[\mathrm{h}]$ & $\mathrm{t}_{3 /} \mathrm{t}_{\mathrm{r}}$ \\
\hline $\mathrm{A}$ & 7.0 & 6230 & 51921 & 0.12 \\
$\mathrm{~B}$ & 3.5 & 7600 & 23616 & 0.32 \\
$\mathrm{C}$ & 0.86 & 21500 & 37890 & 0.57 \\
\hline
\end{tabular}

Table 5 Summary of minor phases identified in the Cast B

\begin{tabular}{|c|c|}
\hline $\mathrm{t}_{\mathrm{r}}[\mathrm{h}]$. & Minor Phases \\
\hline 483 & $\begin{array}{l}\text { prim. Z-phase, sec. Z-phase, } M_{23} C_{6} \text {, very small amounts of } \eta \text {-Laves and } \\
M_{6} X\end{array}$ \\
\hline 936 & $\begin{array}{l}\text { prim. Z-phase, sec. Z-phase }(\uparrow), \eta \text {-Laves }(\uparrow), M_{23} C_{6}(\downarrow) \text {, a small amount } \\
\text { of } M_{6} X\end{array}$ \\
\hline 6195 & prim. Z-phase, sec. Z-phase $(\uparrow), \eta$-Laves $(\uparrow), \mathrm{M}_{23} \mathrm{C}_{6}(\downarrow), \mathrm{M}_{6} \mathrm{X}(\uparrow)$ \\
\hline 14864 & $\begin{array}{l}\text { prim. Z-phase, sec. Z-phase }(\uparrow), \sigma \text {-phase, } \eta \text {-Laves }(\uparrow), M_{23} C_{6}(\downarrow), M_{6} X \\
\text { ( } \uparrow)\end{array}$ \\
\hline 58936 & $\sigma$-phase $(\uparrow)$, prim. Z-phase, sec. Z-phase $(\uparrow), \eta$-Laves $(\uparrow), \mathrm{M}_{6} \mathrm{X}(\uparrow)$ \\
\hline
\end{tabular}

Note: $(\uparrow)$ indicates a phase forming during the creep exposure and $(\downarrow)$ a phase dissolving. 
Table 6 Summary of minor phases identified in the Cast $\mathrm{C}$

$\mathrm{t}_{\mathrm{r}}[\mathrm{h}$.$] \quad Minor Phases$

81 prim. Z-phase, sec. Z-phase, $\mathrm{M}_{23} \mathrm{C}_{6}$, small amounts of $\eta$-Laves and $\mathrm{M}_{6} \mathrm{X}$

$1350 \quad$ prim. Z-phase, sec. Z-phase $(\uparrow), \eta$-Laves $(\uparrow), \mathrm{M}_{23} \mathrm{C}_{6}(\downarrow), \mathrm{M}_{6} \mathrm{X}(\uparrow)$, a small amount of $\sigma$-phase

7849 prim. Z-phase, sec. Z-phase $(\uparrow), \sigma$-phase $(\uparrow), \eta$-Laves $(\uparrow), M_{23} C_{6}(\downarrow), M_{6} X$ $(\uparrow)$

26505 prim. Z-phase, sec. Z-phase $(\uparrow), \sigma$-phase $(\uparrow), \eta$-Laves $(\uparrow), \mathrm{M}_{23} \mathrm{C}_{6}(\downarrow), \mathrm{M}_{6} \mathrm{X}$ $(\uparrow)$

$37890 \quad \sigma$-phase $(\uparrow)$, prim. Z-phase, sec. Z-phase $(\uparrow), \eta$-Laves $(\uparrow), M_{6} X(\uparrow)$, a very small amount of $\mathrm{M}_{23} \mathrm{C}_{6}$

Note: $(\uparrow)$ indicates a phase forming during the creep exposure and $(\downarrow)$ a phase dissolving.

Table 7 The weight ratios $\mathrm{Nb} / \mathrm{C}$ and $\mathrm{Nb} /(\mathrm{C}+6 / 7 \mathrm{~N})$ in the Casts $\mathrm{B}$ and $\mathrm{C}$

\begin{tabular}{ccc}
\hline Cast & $\mathrm{Nb} / \mathrm{C}$ & $\mathrm{Nb} /(\mathrm{C}+6 / 7 \mathrm{~N})$ \\
\hline $\mathrm{B}$ & 4.6 & 0.7 \\
\hline $\mathrm{C}$ & 14.2 & 1.9 \\
\hline
\end{tabular}

Table 8 Chemical composition of minor phases in the Cast B $\left(650^{\circ} \mathrm{C} / 58936 \mathrm{~h}\right.$.), wt.\%

\begin{tabular}{cccccccc}
\hline Phase & $\mathrm{Si}$ & $\mathrm{Cr}$ & $\mathrm{Mn}$ & $\mathrm{Fe}$ & $\mathrm{Ni}$ & $\mathrm{Nb}$ & $\mathrm{Mo}$ \\
\hline $\mathrm{M}_{6} \mathrm{X}$ & 8 & 36 & 1 & 4 & 27 & 2 & 22 \\
$\eta$-Laves & 5 & 12 & 1 & 32 & 3 & 1 & 46 \\
$\sigma$-phase & 1 & 34 & 1 & 52 & 3 & 1 & 8 \\
\hline
\end{tabular}

